\title{
ÖRGÜTSEL ÖĞRENME YETENEĞİ: AMPİRİK ARAŞTIRMALAR ÜZERİNE BİR İNCELEME
}

\section{Gizem YILMAZ KOZCU*, Ömür Neczan TİMURCANDAY ÖZMEN** öz}

Örgütsel öğrenme yeteneği konusuna yönelik araştırmalar son yıllarda artış göstermektedir. Fakat bu konu ile ilgili genel araştırmalar göz önünde bulundurulduğunda, kapsamlı bir doküman analizi eksikliği göze çarpmaktadır. Söz konusu eksikliği gidermek amacıyla bu çalışma 1994 ve 2018 yılları arasında yayınlanan 111 örgütsel öğrenme yeteneği makalesinin geniş bir değerlendirmesini sunmaktadır. Yapılan incelemeler sonucunda, örgütsel öğrenme yeteneği konusu ile ilgili çalışmaların yıllara göre dağıımı, konunun öncülleri ve sonuçları, konu ile ilgili çalışmalarda sık kullanılan ölçekler ve dergilerin yayınlandığı veritabanları belirlenmiştir.

Anahtar Sözcükler: Örgütsel Öğrenme Yeteneği, Öğrenme Yeteneği.

\section{ORGANIZATIONAL LEARNING CAPABILITY: A REVIEW OF EMPIRICAL RESEARCH}

\begin{abstract}
Research on organizational learning capability has been increasing in recent years. However, considering the general researches on this subject, the lack of a comprehensive document analysis is outstanding. In order to remedy the deficiency, this study presents a wide evaluation of 111 organizational learning capability articles published between the years of 1994 and 2018. As a result of the examinations, distribution of studies related to the subject of organizational learning capability by years, antecedents and outcomes of the subject, the scales commonly used in related studies, and databases of published articles are defined.
\end{abstract}

Keywords: Organizational Learning Capability, Learning Capability.

*Dokuz Eylül Üniversitesi, İşletme Fakültesi, İngilizce İşletme Bölümü (Doktora Öğrencisi), İzmir, E-posta: gizemyilmazkozcu@gmail.com **Dokuz Eylül Üniversitesi, İşletme Fakültesi, İşletme Bölümü, İzmir, Eposta: omur.ozmen@deu.edu.tr

(iD) https://orcid.org/0000-0002-3379-317X 


\section{Gizem Yılmaz Kozcu and Ömür Neczan Timurcanday Özmen INTRODUCTION}

Nowadays, organizations are running in a turbulent and mobile business life (Mintzberg, 1994). There is a need to perceive new information so organizations should learn the happenings in the business environment. Therefore, organizations should have the capability of learning. The concept of organizational learning capability (OLC) has identified by several researchers. Starting from the base of this concept, organizational learning is defined by Simon (1969) as a widening insight and accomplished restructuring of organizations. In addition, Argyris and Schön (1978) suggested a definition that it is a knowledge transformation of the external and internal surroundings; at the same time, organizational learning provides a competitive advantage. In addition, organizational learning is an organizational talent to incessantly boost how to learn in order to give up old practices (Senge et al. 1999). By giving up old practices, organizations can achieve latest information. Apart from these, organizational learning reduce the matter of getting obscure information. It supports the healthy processing; at the same time, it prevents organizations from a negative swap of information (Schulz, 2002: 415).

However, at current times, there has been a slight movement from the main situation of learning to a capability side (Armstrong, 2000). One of the reasons of this movement is the aim of improving performance of organizations. The permanent successful performance of an organization is related with the comprehension of learning for an answer to internal and external changes. So as to overcome complexity and complications of work environment, current studies on organizational theory and business are successes the learning capability (Lewin, 2000). In order to maintain the success, organizations should have the learning capability. Organizational learning capability shows organization's ability of adaptation to continually altering business situations. The notion of organizational learning capability ensures accomplishment of significant operations by coping with ambiguities and uncertainties (Styhre, Josephson, and Knauseder, 2004). That is, the possible accomplishments may achieved through the capability of learning (Slater and Narver, 1994).

\section{LITERATURE REVIEW}

The notion of organizational learning capability (OLC) has gained a significance in today's business life. One of the major causes of the 


\section{Organizational Learning Capability: A Review of Empirical Research}

importance of this notion is the requirement of innovation because there is a requirement of handling with the complications and rivalries in the floating business life (Camps et al. 2011). OLC was defined by many researchers. First of all, organizational learning capability is an administrative feature which ease the organizational learning process (Chiva et al. 2007). OLC has organizational talent in order to operate information which comes from outside of the company. Also, OLC helps to reveal a cognitive status related with organizational development (Gomez et al., 2005).

Furthermore, organizational learning capability can be identified as a talent of an organization because this concept helps to achieve to convenient management practices, programs, and processes that simplify and promote learning in workplace (Popper and Lipshitz; 1998; Goh, 1998). Additionally, OLC helps organizations to move from a current situation to requested forthcoming status (Goh, 2003). Therefore, OLC can be seen as an important characteristic which provides organizational

movement. At the same time, OLC can be figured out as a factor which simplify the process of learning in the workplace (Dibella et al. 1996; Hult and Ferrell, 1997). Apart from these definitions, Ulrich et al. (1993) defined organizational learning capability as a strength of managers to form organizational ideas successfully.

From a different perspective, Hsu and Fang (2009) describes organizational learning capability as a talent of an organization that assimilates and converts information into a product improvement together with creating competitive advantage and achieving upper production velocity. Additionally, improving or boosting OLC in business life ensures a huge strength in order to achieve to the persistence of organizations (Akgün et al. 2007). Organizations which have capability to learn shows a great degree of sensation, improvement, and relevance. Therefore, they can survive better than other companies in a competitive business life (Camps et al. 2011). As a result, organizational learning capability has been considered as an important talent because it provides several achievements such as high performance, innovativeness, and productiveness. Therefore, the aim of an organization is to create work areas where there is a superior degree of learning capability (Guinot, Chiva, and Mallen, 2016).

\section{INVESTIGATION METHOD}

In this study, the concept of organizational learning capability was aimed to analyze under a documentation analysis. First of all, it was 
Gizem Yılmaz Kozcu and Ömür Neczan Timurcanday Özmen

decided to explore distribution of OLC studies by years. In addition, it was aimed to find antecedents and outcomes of the concept of organizational learning capability. Further, measurements of OLC were analyzed so as to find mostly preferred scales of this concept. In order to find answer to these issues journals which were published between the years of 1994 and 2018 were reviewed.

In the analysis of data, qualitative research method was used. This qualitative search handled by making literature review. In this stage journals were reviewed in detail from the most preferred academic databases such as Scopus, Complementary Index, Business Source Complete, and etc. In total 174 studies were obtained but 111 articles were selected to evaluate for this study.

\section{FINDINGS}

Within the scope of this part, the findings of analysis are offered. First of all, it was aimed to determine the distribution of organizational learning capability articles according to specific year intervals. The aim of this stage is to determine whether the interest in organizational learning capability has increased or decreased. Therefore, the number of academic articles published on organizational learning capability are shown in a figure which has 5-year time intervals.

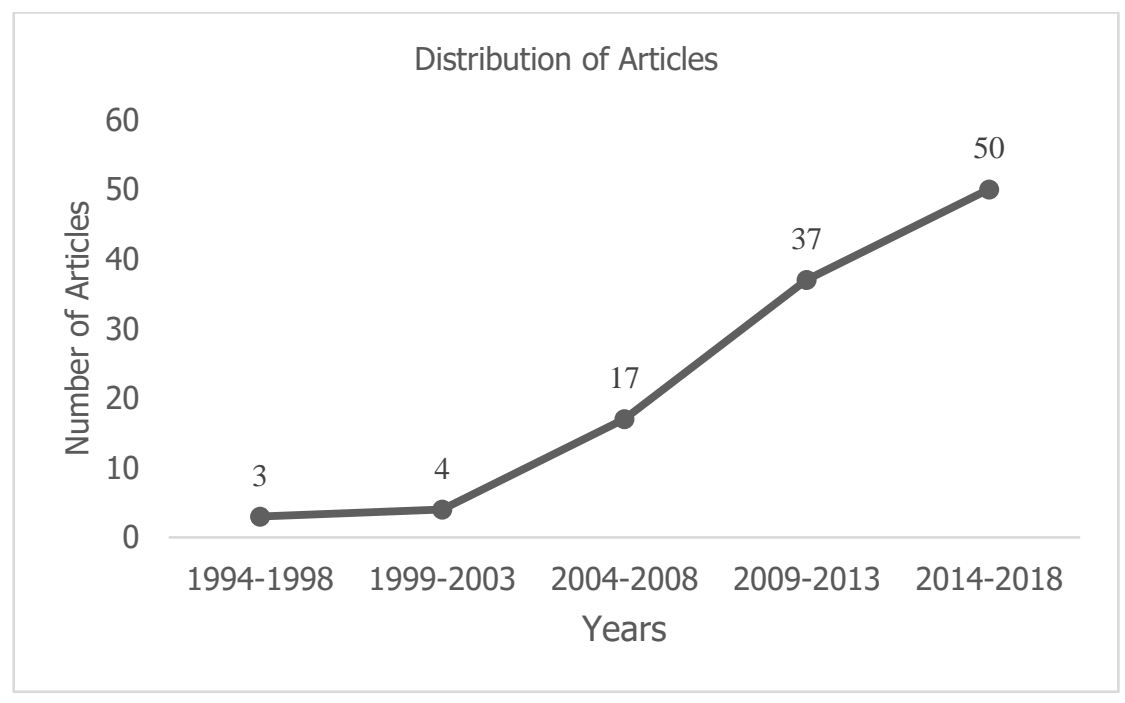

Figure 1: Distribution of Articles by Years 


\section{Organizational Learning Capability: A Review of Empirical Research}

It is demonstrated that interest in the subject of organizational learning capability is increasing substantially. There are three articles within the years of 1994-1998, four articles within the years of 19992003, seventeen articles within the years 2004-2008, thirty seven articles within the years of 2009-2013, and there are fifty articles within the last time period.

Secondly, determination of the most effective databases was aimed in this study. It is regarded that the database effectiveness is significant since it works as a directory as to which databases should be centered on while carrying out a further research about organizational learning capability. With another saying, this study contains the number of articles which published in several databases. The aim of this analysis is to find richest databases in terms of number of published articles related with OLC. In this sense, the top 11 databases with the number of publications they provide are listed in a table.

\section{Table 1: Most Influential Databases}

\begin{tabular}{lll} 
Databases & Number of Articles & Percentage (\%) \\
\hline Complementary Index & 44 & 30,8 \\
Scopus $\AA$ & 24 & 16,8 \\
ScienceDirect & 18 & 12,6 \\
Social Sciences Citation Index & 15 & 10,5 \\
Emerald Insight & 13 & 9,1 \\
Directory of Open Access Journals & 12 & 8,4 \\
Academic Search Complete & 4 & 2,8 \\
Business Source Complete & 4 & 2,8 \\
ERIC & 4 & 2,8 \\
Supplemental Index & 3 & 2,1 \\
MEDLINE & 2 & 1,3 \\
Total & 143 & 100 \\
\hline
\end{tabular}

It can be observed that Complementary Index with $30,8 \%$ is the most influential database in terms of published articles related with organizational learning capability. Complementary Index followed by Scopus ${ }^{\circledR}$, ScienceDirect, Social Sciences Citation Index, Emerald Insight, Directory of Open Access Journals, and other databases shown in the table respectively. Thus, it is thought that if the researchers who will start a new study on organizational learning capability concept examine this table, it can provide them convenience.

In addition, antecedents and outcomes of organizational learning capability were searched. The aim of this analysis is to identify the most 


\section{Gizem Yılmaz Kozcu and Ömür Neczan Timurcanday Özmen}

commonly used topics and encourage to increase interest on less studied topics. In terms of antecedents of organizational learning capability, eight diversified concepts were observed for the three time frames. This analysis starts with the year of 2004 because approximately since that year the concept of OLC was started to be worked with other concepts by researchers.

Table 2: Antecedents of Organizational Learning Capability

\begin{tabular}{lllll} 
Variable & Total & 2004-2008 & 2009-2013 & 2014-2018 \\
\hline Altruism & 2 & - & - & 2 \\
Altruistic Leader Behavior & 2 & - & - & 2 \\
Entrepreneurial Orientation & 4 & - & 2 & 2 \\
HRM & 2 & - & 1 & 1 \\
Intellectual Capital & 2 & - & 2 & - \\
Organizational Trust & 3 & - & 1 & 2 \\
TQM & 4 & 1 & 1 & 2 \\
Training Investments & 2 & 2 & - & - \\
Total & 21 & 3 & 7 & 11 \\
\hline
\end{tabular}

According to results of analysis entrepreneurial orientation and total quality management (TQM) are the most common providers of organizational learning capability. To explain briefly, entrepreneurial orientation affects positively the organizational learning capability (Alegre and Chiva, 2013). On the other side, TQM and organizational learning capability are studied together, mostly. TQM provides organizations to capture, comment, translate or distribute the knowledge, talents and attitudes of employees along with the organization in order to construct organizational learning capability (Akgün, Ince, Imamoğlu, Keskin, and Kocoğlu, 2014).

Wiig (1997) states that intellectual capital includes each assets which are created by intellectual activities like knowledge acquisition and innovation. Importantly, intellectual capital impresses and develops organizational learning capability. Therefore, human capital, structural capital, and relational capital provides organizational learning capability (Hsu and Fang, 2009). In addition, altruistic leader behavior is another common antecedent of organizational learning capability. Leader types like servant, spiritual, transformational or authentic leadership which contain altruism as a fundamental driver have been determined in the literature as antecedents of organizational earning capability (Dominguez-Escrig et al. 2016). In addition, human resource management (Lopez-Cabrales, Real, and Valle, 2011), organizational trust (Tirelli and Goh, 2015; Guinot, Chiva, and Mallen, 2013), training 


\section{Organizational Learning Capability: A Review of Empirical Research}

investments (Brinkerhoff, 2006) are found as antecedents of the organizational learning capability.

\section{Table 3: Outcomes of Organizational Learning Capability}

\begin{tabular}{lllll} 
Variable & Total & $2004-2008$ & $2009-2013$ & $2014-2018$ \\
\hline Financial Performance & 2 & - & - & 2 \\
Happiness at Work & 2 & - & - & 2 \\
Job Satisfaction & 2 & 1 & 1 & - \\
$\begin{array}{l}\text { Organizational Innovation } \\
\text { Organizational }\end{array}$ & 17 & - & 7 & 10 \\
Performance & 19 & 5 & 4 & 10 \\
$\begin{array}{l}\text { Product Innovation } \\
\text { Total }\end{array}$ & 8 & 2 & 3 & 3 \\
\hline
\end{tabular}

Considering outcomes of organizational learning capability organizational performance and organizational innovation concepts are generally verified by researchers. To begin with, the relations between organizational learning capability and organizational performance are studied in several studies. Huber (1991) defines organizational learning as a capability within an organization to sustain a successful performance. In addition, Alegre and Chiva (2013) indicated that organizational learning capability has a positive effect on organizational performance. Moreover, Goh et al. (2012) added the meta-analytic investigation of the relationship between organizational learning capability and performance. The researchers' solutions encourage a positive correlation among them. OLC is defined by Jerez-Gomez et al. (2005) as a resolution element for organizational performance and innovation. At the same time giving this definition, researchers indicated a positive correlation between organizational learning capability and organizational performance. In addition, OLC can be considered as a process by which organizations can reform and change their intellectual, processing, intelligence. Therefore, learning capability has a positive effect on organizational performance (Cyert \& March, 1963).

On the other side, correlation between organizational learning and innovation is commonly analyzed by researchers. One reason that brackets this correlation is the diffusion of innovation theory. Inasmuch as, diffusion of innovation theory searches for to express how, why, and in what percentage advanced ideas and technology circulate. (Rogers, 2003). The learning capability of organizations has a strong effect to generate innovation (Sinkula et al., 1997). The concept of innovation is considered by many researchers as an important outcome of OLC. 


\section{Gizem YıImaz Kozcu and Ömür Neczan Timurcanday Özmen}

In terms of product innovation performance, general empirical articles approved the significant influence of organizational learning capability to this concept (Alegre et al., 2012; Li et al., 1999; Alegre and Chiva, 2008). Apart from this, happiness at work (Salas-Vallina, Alegre, and Fernandez, 2017), job satisfaction (Chiva and Alegre, 2009), financial performance (Akgün et al. 2014) are the important outcomes of OLC.

Apart from these investigations, organizational learning capability is accepted as a multidimensional establishment. Although there are many initiatives in developing a measurement scale for OLC, there has been few reliable measurement scales of organizational learning capability. In this stage, the most frequently used measurement scales of organizational learning capability are demonstrated is a table.

\section{Table 4: Commonly Used Scales of OLC}

\begin{tabular}{lll} 
Scales & Total & $(\%)$ \\
\hline $\begin{array}{l}\text { Chiva, Alegre, and Lapiedra (2007)/ Chiva and Alegre } \\
\text { (2009) }\end{array}$ & 32 & 36,36 \\
$\begin{array}{l}\text { Jerez-Gomez, Cespedes-Lorente, and Valle-Cabrera } \\
\text { (2005) }\end{array}$ & 20 & 22,73 \\
Other Scales & & \\
Total & 36 & 40,91 \\
\hline
\end{tabular}

It is demonstrated that scales which developed by Chiva and colloquies (2007) and Chiva and Alegre (2009) are used in 32 studies. This number shows $36,36 \%$ of total studies. Secondly, the scale which is developed by Jerez-Gomez and colloquies (2005) another mostly preferred measurement for researchers. Their scale is used 20 of 88 studies that shows $22,73 \%$ of total evaluated studies. Remaining scales are found generally as a mixture of these two most preferred scales.

In detail, Chiva (2004) examined the subject for specifying the provider elements of organizational learning. Depended on a comprehensive analysis, Chiva et al. (2007) improved an organizational learning capability measurement instrument. They specified five important factors of organizational learning which are named as experimentation, risk taking, interaction with the external environment, dialogue, and participative decision making.

Firstly, experimentation might be described as the degree of current opinions and offers and it is the most seriously promoted factor in the organizational learning literature (Hedberg, 1981; Tannenbaum, 1997; Ulrich et al., 1993; Pedler et al., 1997). Also, experimentation provides current opinions and seriousness inside an organization (Nevis et al., 1995). Secondly, risk taking can be defined as the toleration of 


\section{Organizational Learning Capability: A Review of Empirical Research}

uncertainty, vagueness, and mistakes (Chiva and Alegre, 2009). Thirdly, interaction with the external environment can be described as an extent of interactions with the surrounding (Chiva and Alegre, 2009). On the other hand, dialogue can be described as a sustained research in operations, thoughts, and precisions that composes daily experimentation (Isaacs, 1993: 25). Lastly, participative decision making can be defined as the grade of effect of employees on their decision making process (Cotton et al., 1988). Organizations should give importance to participative decision making so as to achieve to the motivational impacts of improved employee involvement, job satisfaction and organizational commitment (Latham et al., 1994).

On the other side, Jerez-Gomez et al. (2005) supports that an organization can demonstrate a great extent of learning in all departments. They analyzed the organizational learning capability as a multidimensional concept and they named the dimensions as managerial commitment, systems perspective, openness and experimentation, and knowledge transfer and integration. Firstly, under the scope of managerial commitment, management can profess a strategic appearance of learning by doing it a centric visual component and a valued instrument with an effect on the gathering of longtime conclusions (Slocum et al., 1993; Hult and Ferrell, 1997). In addition, management can operate the change, getting the accountability in order to form an organization which may revive itself and bear to current defiance (Lei et al., 1999). Secondly, another dimension is the systems perspective which underlines a path getting the associates of the organization jointly about a joint identification (Senge, 1990). Under this dimension, an organization can be considered as a system that is made of variety pieces. However, it generally perform with an organized style (Stata, 1989; Kofman and Senge, 1993). Thirdly, openness and experimentation takes a region of openness which meets the coming of recent opinions that letting individual knowledge (Senge, 1990; Slocum et al., 1994). Openness to new ideas supports experimentation which is necessary to generate learning. Inasmuch as, openness to new ideas provides innovative resilient solutions (Leonard- Barton, 1993). Lastly, knowledge transfer and integration touches on internal transmission and concretion of knowledge. This dimension emphasizes to the internal obstacles which hinder the transference of best practice inside the organization (Szulanski, 1996). 


\section{Gizem Yılmaz Kozcu and Ömür Neczan Timurcanday Özmen DISCUSSION AND FUTURE RESEARCH DIRECTIONS}

The purpose of this study is to pick out the development process of organizational learning capability in business area through a qualitative research method. This method is used so as to detect the scope of research, research methodology, and empirical matters related to the appropriate literature by means of a content analysis. Progressing the knowledge about the issue, the results work as a guide for the researchers who want to search on organizational learning capability.

In point of the distribution of articles by years, the results emphasis on to the rising interest on organizational learning capability in the last time period. This finding shows that there has been an important interest on organizational learning capability nearly fifteen years. The most intense work time interval of this concept is within the years of 2014-2018. There are fifty articles on the OLC concept within these time intervals.

With regard to the most influential data bases, the findings underline the most inclusive data bases in terms of organizational learning capability concept. The results demonstrates that Complementary Index is the most inclusive database. Following this database Scopus, ScienceDirect, Social Sciences Citation Index, Emerald Insight, Directory of Open Access Journals are found as inclusive databases respectively. In this way, future researchers can start their research on OLC from the databases that are listed first.

On account of antecedents and outcomes of organizational learning capability, the most frequently studied subjects with the concept were tried to find. Findings demonstrate that organizational performance and organizational innovation concepts are the most studied outcomes. On the other side, entrepreneurial orientation and total quality management concepts are commonly studied as antecedents of organizational learning capability. In addition, other frequently used subjects are shown in a table. Thus, researchers who want to develop a research model can benefit from this table. On the other hand, the remaining concepts such as happiness at work, managerial trust and knowledge performance should be studied further with organizational learning capability.

Lastly, in terms of measurement of organizational learning capability, the most frequently used scales were determined. The scales developed by Chiva, Alegre, and Lapiedra (2007) and Chiva and Alegre (2009) with five dimensions are found as the most common measurement for the subject. Following this, the scale developed by Jerez-Gomez, Cespendes-Lorente, and Valle-Cabrera (2005) with four 


\section{Organizational Learning Capability: A Review of Empirical Research}

dimensions is also found to be one of the most preferred scale of OLC. Both of the scales have been generally preferred mostly because they give consistent results. However, because the two scales are a little long, future scholars may aim to develop a shorter scale on this subject.

\section{CONCLUSION}

Learning is a comprehensive concept which associates diversified levels of analysis such as individual, group, corporate. Organizational learning can be defined as the methods organizations build, complement and organize knowledge and routines for their operations (Dodgson, 1993). Organizations can be considered as a living organisms which are learning from past experiences; at the same time, updating its routines (Levitt and March, 1988). Importantly, organizational learning can be improved by constructing on available capabilities. By the same token, organizational learning can be improved by advancing new capabilities. Organizations can develop their learning capability by utilizing both methods (Diabella, Nevis, and Gould, 1996).

Learning capability can be defined as a talent to apply convenient management implementations, structures, and procedures which facilitate the learning in work place (Leonard-Barton, 1992; Garvin, 1993). According to recent definitions given by researchers, organizational learning capability, which touches upon to the organizational capability to learn, has obtained attention to having a fundamental place so as to compete in the long run. Inasmuch as, organizational learning capability facilitates an organization to get over difficulties of turbulent business environments and strengthen performance (Chiva et al., 2007; Jerez-Gomez et al., 2005). That is, organizational learning capability is an ability of an organization to achieve competitive advantage with powerful outputs. Thus, in order to have successful performance and stronger innovativeness, organizations should obtain the capability of learning.

\section{REFERENCES}

Akgün, A. E, Ince, H, Imamoglu, S. Z, Keskin, H. and Kocoglu, I. (2014). The Mediator Role of Learning Capability and Business Innovativeness between Total Quality Management and Financial 


\section{Gizem Yılmaz Kozcu and Ömür Neczan Timurcanday Özmen}

Performance. International Journal of Production Research, 52(3), 888-901.

Akgün, A. E, Keskin, H, Byrne, J. C. and Aren, S. (2007). Emotional and Learning Capability and their Impact on Product Innovativeness and Firm Performance. Technovation, 27(9), 501-513.

Alegre, J. and Chiva, R. (2008). Assessing the Impact of Organizational Learning Capability on Product Innovation Performance: An Empirical Test. Technovation, 28(1), 315-326.

Alegre, J. and Chiva, R. (2013). Linking Entrepreneurial Orientation and Firm Performance: The Role of Organizational Learning Capability and Innovation Performance. Journal of Small Business Management, 51(4), 491-507.

Alegre, J, Pla-Barber, J, Chiva, R. and Villar, C. (2012). Organisational Learning Capability, Product Innovation Performance and Export Intensity. Technology Analysis and Strategic Management, 24(5), 511-526.

Argyris, C. and Schön, D.A. (1978). Organizational Learning: A Theory of Action Perspective. MA: Addison-Wesley.

Armstrong, M. (2000). The Name Has Changed but Has the Game Remained the Same? Employee Relations, 22(6), 576-89.

Brinkerhoff, R. O. (2006). Increasing Impact of Training Investments: An Evaluation Strategy for Building Organizational Learning Capability. Industrial and Commercial Training, 38(6), 302-307.

Camps, J, Alegre, J. and Torres, F. (2011). Towards a Methodology to Assess Organizational Learning Capability: A Study Among Faculty Members. International Journal of Manpower, 32(5), 687-703.

Chiva, R. (2004). The Facilitating Factors for Organizational Learning in the Ceramic Sector. Human Resource Development International, $7(2), 233-249$.

Chiva, R. and Alegre, J. (2009). Organizational Learning Capability and Job Satisfaction: An Empirical Assessment in the Ceramic Tile Industry. British Journal of Management, 20(3): 323-340.

Chiva, R, Alegre, J. and Lapiedra, R. (2007). Measuring Organizational Learning Capability among the Workforce. International Journal of Manpower, 28(3), 224-242.

Cotton, J.L, Vollrath, D.A, Foggat, K.L, Lengnick-Hall, M.L. and Jennings, K.R. (1988). Employee Participation: Diverse Forms and Different Outcomes. Academy of Management Review, 13(1), 8-22.

Cyert, R. and March, J. G. (1963). A Behavioral Theory of the Firm. Englewood Cliffs: Prentice Hall. 


\section{Organizational Learning Capability: A Review of Empirical Research}

Dibella, A. J, Nevis, E. C. and Gould, J. M. (1996). Understanding Organizational Learning Capability. Journal of Management Studies, 33(1), 361-379.

Dodgson, M. (1993). Organizational Learning: A Review of Some Literatures. Organization Studies, 14(3), 375-394.

Dominguez-Escrig, E, Mallen-Broch, F. F, Chiva-Gomez, R. and LapiedraAlcami, R. (2016). How does Altruistic Leader Behavior Foster Radical Innovation? The Mediating Effect of Organizational Learning Capability. Leadership and Organization Development Journal, 37(8), 1056-1082.

Goh, S.C, Elliot, C. and Quon, T.K. (2012). The Relationship between Learning Capability and Organizational Performance: A MetaAnalytic Examination. The Learning Organization, 19(2), 92-108.

Goh, S. C. and Richards, G. S. (1997). Benchmarking the Learning Capability of Organizations. European Management Journal, 15(5), 575-583.

Guinot, J, Chiva, R. and Mallen, F. (2013). Organizational Trust and Performance: Is Organizational Learning Capability a Missing Link? Journal of Management and Organization, 19(5), 559-582.

Guinot, J, Chiva, R. and Mallen, F. (2016). Linking Altruism and Organizational Learning Capability: A Study from Excellent Human Resources Management Organizations in Spain. Journal of Business Ethics, 138(2), 349-364.

Hedberg, B. (1981). How organizations learn and unlearn. In P. C. Nystrom and W. H. Starbuck (Eds.). Handbook on Organizational Design. Oxford: Oxford University Press.

Huber, G. (1991). Organizational Learning: The Contributing Processes and Literature. Organization Science, 2(1), 88-115.

Hult, T. and Ferrell, O.C. (1997). Global Organizational Learning Capacity in Purchasing: Construct and Measurement. Journal of Business Research, 40(2), 97-111.

Hsu, Y.H. and Fang, W. (2009). Intellectual Capital and New Product Development Performance: The Mediating Role of Organizational Learning Capability. Technological Forecasting and Social Change, 76 (1), 664-677.

Isaacs, W. (1993). Taking Flight: Dialogue, Collective Thinking, and Organizational Learning. Organizational Dynamics, 22, 24-39.

Jerez-Gomez, P, Cespedes-Lorente, J. and Valle-Cabrera, R. (2005). Organizational Learning Capability: A Proposal of Measurement. Journal of Business Research, 58 (1), 715-725. 


\section{Gizem Yılmaz Kozcu and Ömür Neczan Timurcanday Özmen}

Kofman, F. and Senge, P. (1993). Communities of Commitment: The Heart of Learning Organizations. Organizational Dynamics, 22(2), 5-23.

Latham, G.P, Winters, D.C. and Locke, E.A. (1994). Cognitive and Motivational Effects of Participation: A Mediator Study. Journal of Organizational Behavior, 15(1), 49-63.

Lei, D. Slocum, J.W. and Pitts, R.A. (1999). Designing Organizations for Competitive Advantage: The Power of Unlearning and Learning. Organizational Dynamics, 37(3), 24-38.

Leonard-Barton, D. (1992). The Factory as Learning Laboratory. Sloan Management Academy, Fall, 23-38.

Levitt, B. and March, J. G. (1988). Organizational Learning. Annual Review of Sociology, 14(1), 319-340.

Li, T, Nicholls, J. A. F. and Roslow, S. (1999). The Relationships between Market-Driven Learning and New Product Success in Export Markets. International Marketing Review, 16(6), 476-503.

Lopez-Cabrales, A, Real, J. and Valle, R. (2011). Relationships between HRM Practices and OLC. The Mediating role of Human Capital. Personnel Review, 40(3), 344-363.

Mintzberg, H. (1994). The Rise and Fall of Strategic Planning. Englewood Cliffs: Prentice-Hall.

Nevis, E.C, DiBella, A.J. and Gould, J.M. (1995). Understanding Organizations as Learning Systems. Sloan Management Review, 36(2), 73-86.

Pedler, M, Burgoyne, J. and Boydell, P. (1997). The Learning Company: A Strategy for Sustainable Development. Maidenhead: McGraw-Hill.

Salas-Vallina, A, Alegre, J. and Fernandez, R. (2017). On the Road to Happiness at Work (HAW): Transformational Leadership, Organizational Learning Capability and Happiness at Work. Personnel Review, 46(2), 314-338.

Senge, P. (1990). The Fifth Discipline: The Art and Practice of the Learning Organization. New York: Doubleday.

Senge, P, Kleiner, A, Roberts, C, Ross, R, Roth, G. and Smith, B. (1999). The Dance of Change. New York: Doubleday.

Simon, H. A. (1969). Sciences of the Artificial. Cambridge: M.I.T. Press.

Slater, S. F. and Narver, J. C. (1994). Does Competitive Environment Moderate the Market Orientation-Performance Relationship? Journal of Marketing, 58(1), 46-55.

Slocum, J.W, McGill, M. and Lei, D.T. (1994). The New Learning Strategy: Anytime, Anything, Anywhere. Organizational Dynamics, 23(2), 3347. 


\section{Organizational Learning Capability: A Review of Empirical Research}

Stata, R. (1989). Organizational Learning: The Key to Management Innovation. Sloan Manage Review, 30(3), 63-74.

Styhre, A, Josephson, P. and Knauseder, I. (2004). Learning Capabilities in Organizational Networks: Case Studies of Six Construction Projects. Construction Management and Economics, 22(9), 957966.

Szulanski, G. (1996). Exploring Internal Stickiness Impediments to the Transfer of Best Practice within the Firm. Strategic Management Journal, 17, 27-44.

Tannenbaum, S.I. (1997). Enhancing Continuous Learning: Diagnostic Findings from Multiple Companies. Human Resource Management, 36(4), 437-452.

Tirelli, A. and Goh, S. C. (2015). The Relationship between Trust, Learning Capability, Affective Organizational Commitment and Turnover Intentions. International Journal of Human Resources Development and Management, 15(1), 54-68.

Ulrich, D, Jick, T. and Von Glinnow, M. (1993). High Impact Learning: Building and Diffusing Learning Capability. Organizational Dynamics, 22(2), 52-66.

Wiig, K.M. (1997). Knowledge Management: Where Did It Come From and Where Will It Go? Expert Systems with Applications, 13(1), 114. 